\title{
PERENCANAAN MANAJEMEN PROYEK DALAM MENINGKATKAN EFISIENSI DAN EFEKTIFITAS SUMBER DAYA PERUSAHAAN (Studi Kasus : Qiscus Pte Ltd)
}

\author{
Ganesstri Padma Arianie*), Nia Budi Puspitasari \\ Jurusan Teknik Industri, Fakultas Teknik, Universitas Diponegoro \\ Jl. Prof H. Soedharto, SH, Kampus Undip Tembalang, Semarang, Indonesia 50275
}

(Received: August 11, 2017/ Accepted: September, 2017)

\begin{abstract}
Abstrak
Manajemen proyek merupakan strategi yang perlu dilakukan dalam mencapai efisiensi dan efektifitas suatu perusahaan. Perkembangan pada era teknologi masa ini sejalan dengan berkembangnya perusahaan yang bergerak di bidang jasa teknologi, seperti Qiscus Pte Ltd. Perencanaan proyek tersebut dapat disusun menggunakan Work Breakdown Structure (WBS), Cirital Path Method (CPM) dan Program Evaluation and Review Technique (PERT). Manajemen proyek dapat pula digunakan untuk memperkirakan adanya percepatan proyek (crasing) pada Qiscus Pte Ltd. Dengan penyusunan suatu manajemen proyek yang baik, maka dapat dilakukan estimasi waktu dan biaya yang diperlukan dalam menjalankan proyek, sehingga dapat meminimasi kerugian biaya akibat kemungkinan keterlambaran proyek. Perencanaan manajemen proyek yang dilakukan untuk menjalankan proyek Hayyan, Qiscus Pte Ltd, menghasilkan estimasi percepatan pengerjaan proyek selama 6 hari, dengan penambahan biaya sebesar 2,8 juta.
\end{abstract}

Kata kunci : Manajemen Proyek, WBS, CPM, PERT, Crasing

\begin{abstract}
Project management is a strategy that needs to be done in achieving the efficiency and effectiveness of a company. Technology development in this era is along with the development company engaged in technology services, such as Qiscus Pte Ltd. Planning the project can be compiled using a Work Breakdown Structure (WBS), Cirital Path Method (CPM) and Program Evaluation and Review Technique (PERT). Project management can also be used to estimate the acceleration of the project (crasing) on Qiscus Pte Ltd. The preparation of a good project management can estimate the time and cost required to run the project, so as to minimize losses due to the possibility of delays in project costs.
\end{abstract}

Keywords : Project Management, WBS, CPM, PERT, Crasing

\section{Pendahuluan}

Pemanfaatan teknologi era kini terus dikembangkan hingga bertujuan untuk meningkatkan opportunity yang didapatkan. Perkembangan ini sejalan dengan berkembangnya perusahaan yang bergerak di bidang jasa teknologi yang berperan sebagai konsultan dan jasa penyedia perangkat lunak. Hal ini yang menjadi salah satu alasan perusahaan Qiscus Pte Ltd atau PT. Sinergitas Mandiri Infokom menjadi perusahaan yang terus berkembang seiring dengan permintaan proyek meningkat pada tahun 2016 seperti pada Gambar 1.
Adanya permintaan proyek yang meningkat pada Tahun 2016 memberikan peluang Qiscus Pte Ltd untuk dapat meningkatkan keuntungan perusahaan, tetapi di sisi lain peningkatan atas permintaan proyek tersebut dapat menjadi masalah dalam perusahaan apabila tidak memiliki manajemen perusahaan yang baik. Manajemen proyek dibuat untuk dapat menghindari atau meminimalisir kegagalan dan resiko proyek (Noerlina, 2008). Manajemen yang baik terkait dengan menejemen aktivitas seperti penjadwalan, pengelolaan human resource yang mana akan berujung pada estimasi biaya proyek yang perlu dianggarkan perusahaan.

\footnotetext{
*) Penulis Korespondensi.

Email : ganesstripad@gmail.com
} 


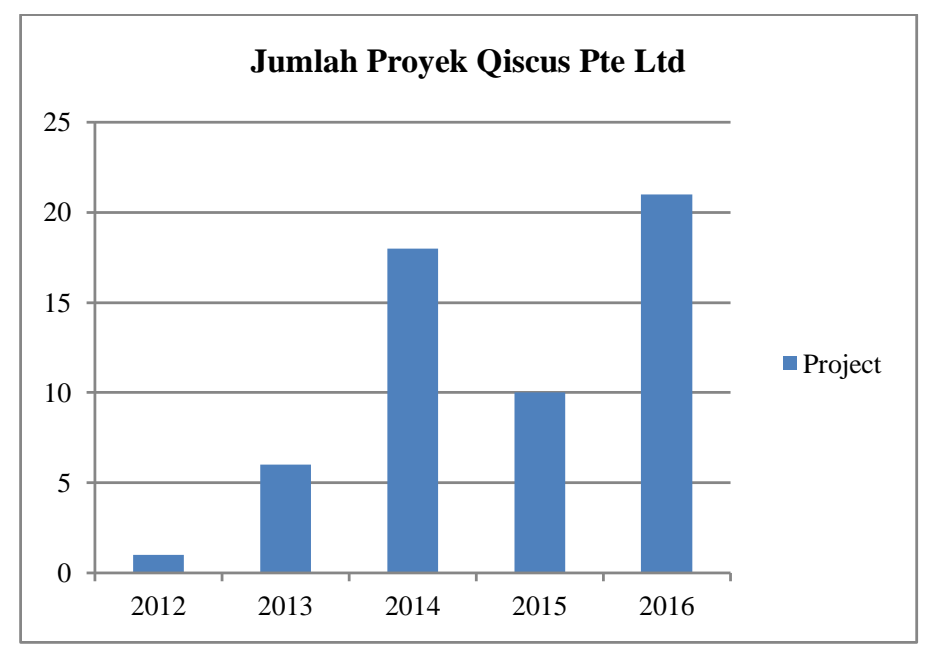

Gambar 1. Jumlah Proyek Qiscus Pte Ltd Tahun 2012-2016

Pada penelitian sebelumya, yaitu penelitian Noerlina (2008), diketahui bahwa membangun manajemen proyek yang baik mampu menciptakan tahap pelaksanaan proyek lebih terperinci dan efisien.

Perusahaan perlu berupaya untuk meningkatkan kualitas jasa yang diberikan dengan melalui pembuatan perencanaan yang terstruktur, sehingga lebih optimal dalam penggunaan sumber daya yang akan berdampak pada efesiensi kinerja internal perusahaan. Tanpa adanya manajemen proyek yang baik tersebut dapat menurunkan performa kerja perusahaan untuk memenuhi permintaan pelanggan. 2 dari 10 proyek atau sebesar 20\% proyek yang dijalankan Qiscus Pte Ltd pada Tahun 2015 tidak terselesaikan sesuai dengan perencanaan proyek yang dibuat. Apabila terjadi keterlambatan proyek maka kompensasi yang diberikan pihak manajemen pada client berupa pengembalian sejumlah uang yang telah disepakati pada awal perjanjian dan jika keterlambatan lebih dari 1 minggu maka seluruh biaya yang dibayarkan client akan dikembalikan. Berdasarkan laporan keuangan Tahun 2014-2015 yang disampaikan CTO perusahaan, terjadi kerugian yang diakibatkan adanya keterlambatan proyek sebesar 5\% dari pendapatan tahunan. Untuk menghindari adanya peningkatan kerugian dari tahun-tahun sebelumnya, sehingga perencanaan manajemen proyek yang baik adalah solusi yang dapat dilakukan.

Dalam upaya mempertahankan kesetiaan pelanggan menggunakan jasa dari Qiscus Pte Ltd, maka perusahaan perlu selalu berupaya menyusun manajemen proyek yang baik. Salah satu proyek yang dilakukan Qiscus Pte Ltd adalah proyek Hayyan, yaitu proyek dalam pembuatan website. Tujuan penelitian ini adalah:

1. Menyusun aktivitas global proyek Hayyan dalam bentuk Work Breakdown Structure.
2. Membuat perencanaan/ penjadwalan proyek dengan Cirital Path Method (CPM) dan Program Evaluation and Review Technique (PERT).

3. Mengidentifikasi komponen biaya untuk Proyek Hayyan

4. Menganalisis trade off dari penggunaan biaya normal dan biaya crashing dalam menjalankan proyek Hayyan

\section{Studi Literatur}

Menurut Dimyati dan Nurjaman (2014), Manajemen proyek merupakan proses merencanakan, mengorganisasikan, memimpin, dan mengendalikan kegiatan anggota organisasi serta sumber daya lainnya sehingga dapat mencapai sasaran organisasi telah ditentukan sebelumnya (Soeharto, 1999). Tujuan dari manajemen proyek adalah untuk dapat mengelola fungsi-fungsi manajemen hingga diperoleh hasil optimum sesuai dengan persyaratan yang ada dan telah ditetapkan serta untuk dapat mengelola sumber daya yang seefisien dan seefektif mungkin.

\section{Fungsi Manajemen Proyek}

Beberapa fungsi dari manajemen proyek (Dimyati dan Nurjaman, 2014), adalah:

1. Fungsi perencanaan (Planning)

Fungsi ini bertujuan dalam pengambilan keputusan yang mengelola data dan informasi yang dipilih untuk dilakukan di masa mendatang, seperti menyusun rencana jangka panjang dan jangka pendek, dan lain-lain.

2. Fungsi Organisasi (Organizing)

Fungsi organisasi bertujuan untuk mempersatukan kumpulan kegiatan manusia, yang memiliki aktivitas masing-masing dan saling berhubungan, dan berinteraksi dengan lingkungannya dalam rangka mencapai tujuan 
organisasi, seperti menyusun lingkup aktivitas, lain.

3. Fungsi Pelaksanaan (Actuating)

Fungsi pelaksanaan bertujuan untuk menyelaraskan seluruh pelaku organisasi terkait dalam melaksanakan kegiatan/ proyek, seperti pengarahan tugas serta motivasi, dan lain-lain.

4. Fungsi Pengendalian (Controlling)

Fungsi pengendalian bertujuan untuk mengukur kualitas penampilan dan penganalisisan serta pengevaluasian kegiatan, seperti memberikan saran-saran perbaikan, dan lain-lain.

\section{Work Breakdown Structure}

Work breakdown structure (WBS) merupakan suatu pengelompokkan elemen kerja yang ditunjukkan dalam bentuk grafik untuk mengatur dan membagi keseluruhan ruang lingkup suatu proyek kerja (Rev, 2003).

\section{Critical Path Method (CPM)}

Menurut Schroeder (1996) dalam Dimyati dan Nurjaman (2014), Critical Path Method (CPM) merupakan metode jalur kritis yang menggunakan jaringan dengan keseimbangan waktu-biaya linear. Teknik CPM dilakukan dengan menyusun jaringan kerja yang diidentifikasikan ke arah aktivitasaktivitas dan menggunakan simple time estimates pada tiap aktivitas yang menunjukkan jangka waktu pelaksanaan

Beberapa istilah yang digunakan dalam metode CPM ini adalah:

a. Earliest Start Time (ES)

ES merupakan waktu tercepat suatu kegiatan/ aktivitas dapat dimulai, dengan memperhatikan waktu kegiatan dan persyaratan pada urutan pengerjaan kegiatan.

b. Latest Start Time (LS)

LS merupakan waktu paling lambat untuk memulai suatu kegiatan.

c. Earliest Finish Time (EF)

EF merupakan waktu tercepat kegiatan dapat diselesaikan.

d. Latest Finish Time (LF)

LF merupakan waktu paling lambat dalam menyelesaikan suatu kegiatan.

Pada CPM dikenal istilah critical path atau jalur kritis yang bertujuan untuk mengetahui kegiatankegiatan yang memiliki tingkat kepekaan tinggi terhadap keterlambatan pelaksanaan, sehingga dapat menentukan tingkat prioritas kebijakan dalam penyelenggaraan proyek.

Bentuk CPM tersebut dapat memberikan informasi terkait dengan kegiatan yang dilaksanakan terlebih dahulu atau sesudahnya, dan durasi kegiatan.
Pada CPM dikenal pula istilah slact time, yaitu waktu penundaan suatu kegiatan tanpa mengubah jangka waktu proyek secara keseluruhan. Slack time didapakan dengan menggunakan rumus berikut:

$$
S_{i j}=L S_{i j}-E S_{i j} \text { atau } S_{i j}=L F_{i j}-E F_{i j}
$$

Jaringan yang telah dibuat pada CPM dapat direfleksikan sebagai dasar penjadwalan proyek. Penjadwalan proyek biasa dibuat dalam bentuk grafik Gantt Chart.

\section{Program Evaluation and Review Technique (PERT)}

PERT digunakan dalam melakukan penjadwalan, mengatur dan mengkoordinasikan bagian-bagian kegiatan dalam suatu proyek. Menurut Soeharto (2002), metode PERT mencakup tiga perkiraan waktu, yaitu:

a. Waktu pesimistic $\left(\mathrm{t}_{\mathrm{p}}\right)$, adalah waktu paling panjang yang mungkin diperlukan suatu kegiatan

b. Waktu perkiraan paling mungkin atau most likely $\left(\mathrm{t}_{\mathrm{m}}\right)$, adalah waktu penyelesaian kegiatankegiatan proyek yang paling memungkinkan, atau memiliki probabilitas paling tinggi

c. Waktu Optimistic $\left(\mathrm{t}_{\mathrm{o}}\right)$, adalah waktu tercepat yang dapat dilakukan untuk melaksanakan kegiatan suatu proyek.

Setelah menentukan ketiga perkiraan waktu tersebut, maka kita dapat menentukan waktu kegiatan yang diharapkan (Expected Timed) dengan rumus sebagai berikut:

\section{Expected Time $=$ $\underline{\text { optimistic }+(4 \times \text { most likely })+\text { pesimistic }}$}

Dalam menentukan perkiraan waktu proyek dapat dihitung dengan menggunakan perhitungan probabilitas dan diselesaikan dengan tabel normalitas.

$$
\mathrm{Z}=\frac{x-\mu}{\sigma}
$$

Dengan keterangan bahwa $x$ merupakan jumlah waktu pelaksanaan proyek yang diharapkan, $\mu$ merupakan rata-rata proyek dapat terselesaikan, dan $\sigma$ merupakan standar deviasi.

\section{Percepatan Pelaksanaan Kegiatan (Crashing)}

Crashing merupakan proses mereduksi suatu kegiatan yang akan berpengaruh terhadap waktu penyelesaian proyek. Menurut Ervianto (2014) dalam Dimyati dan Nurjaman (2014), proses Crashing merupakan cara untuk melakukan perkiraan untuk variabel cost dalam menentukan pengurangan durasi yang paling optimal dan ekonomis dari suatu kegiatan proyek yang masih memungkinkan untuk direduksi. 
Crashing dapat memunculkan adanya trade off antara biaya dan waktu.

\section{Metode Penelitian}

Metode yang dilakukan yaitu mulai dari penemuan masalah, penentuan tujuan penelitian, pengumpulan dan pengolahan data. Tahap yang dilakukan untuk pengolahan data adalah:

- Identifikasi aktivitas proyek dengan menggunakan Work Breakdown Structure (WBS) sederhana.

- Pembuatan alur aktivitas dengan precedence diagram. Untuk menentukan waktu dan biaya pelaksanaan proyek yang efisien, digunakan metode dalam strategi manajemen proyek yaitu CPM, PERT, dan Crashing.

\section{Pembahasan}

\subsection{Identifikasi Aktivitas Proyek}

Dalam melakukan perencanaan manajemen proyek yang baik perlu diawali dengan melakukan identifikasi aktivitas-aktivitas yang dilakukan. Menurut Duncan (1996), ruang lingkup aktivitasaktivitas yang akan dilakukan dalam suatu proyek dapat digambarkan dalam suatu Work Breakdown Structure (WBS) sederhana sehingga didapatkan informasi yang merinci mengenai

\subsection{Perencanaan Aktivitas Global}

Perencanaan aktivitas global dilakukan dengan pengalokasian sumber daya manusia, biaya, dan waktu yang dibutuhkan. Seperti pada Tabel 1 dapat diketahui pekerja-pekerja yang bertanggung jawab dalam pelaksanaan tiap aktivitas sehingga memudahkan dalam melakukan monitoring proyek.

Alur aktivitas yang dilakukan tergambarkan dalam presedence diagram yang tercantum pada Gambar 3. Presedence diagram dibuat berdasarkan Tabel 2. yang menunjukkan urutan.

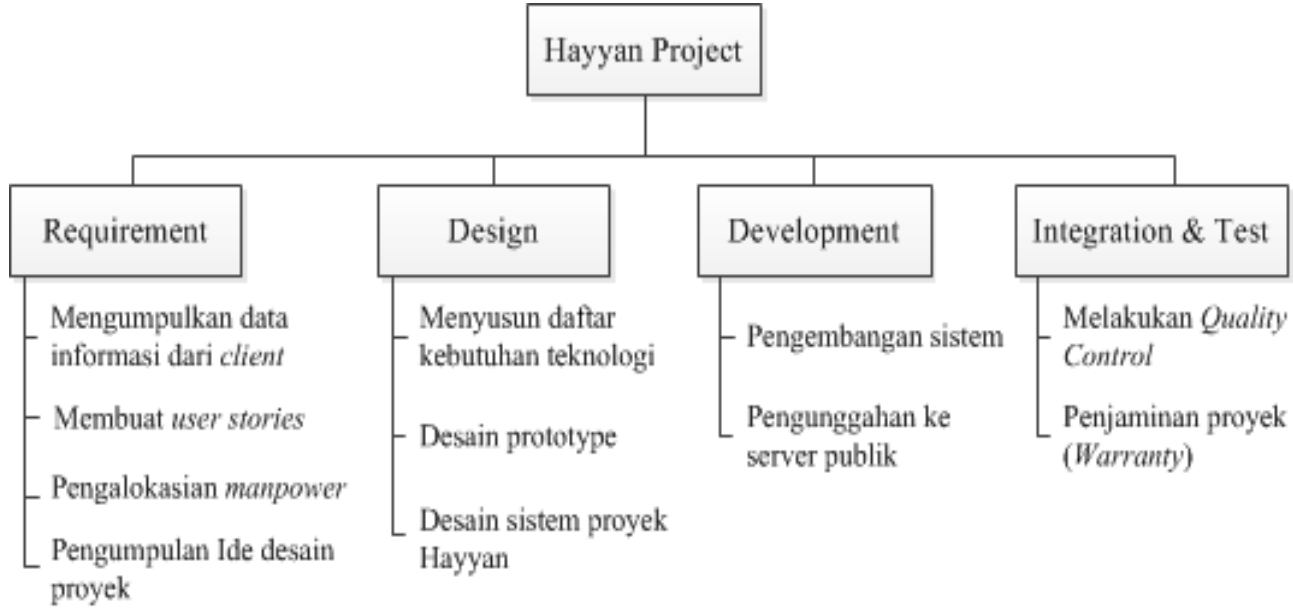

Gambar 2. Work Breakdown Structure

Tabel 1. Alokasi SDM untuk Aktivitas Proyek

\begin{tabular}{cll}
\hline No & \multicolumn{1}{c}{ Deskripsi Aktivitas } & \multicolumn{1}{c}{ PIC } \\
\hline 1. & $\begin{array}{l}\text { Mengumpulkan seluruh kebutuhan data dan informasi dari client } \\
\text { Proyek Hayyan }\end{array}$ & Project Manager \\
\hline 2. & $\begin{array}{l}\text { Membuat user stories atau deskripsi fungsi proyek berdasarkan } \\
\text { kebutuhan dari proyek Hayyan }\end{array}$ & $\begin{array}{l}\text { Project Manager, Desainer, Lead } \\
\text { Programmer }\end{array}$ \\
\hline 3. & Mengalokasikan manpowers & Project Manager \\
\hline 4. & Mengumpulkan ide desain & Desainer \\
\hline 5. & $\begin{array}{l}\text { Menyusun daftar kebutuhan teknologi (software atau hardware) yang } \\
\text { diperlukan }\end{array}$ & Lead Programmer \\
\hline 6. & $\begin{array}{l}\text { Menyusun desain dalam bentuk prototype sebagai langkah awal an } \\
\text { persetujuan perancangan proyek dengan client }\end{array}$ & Desainer \\
\hline 7. & Menyusun desain sistem proyek Hayyan yang telah disetujui oleh client & Lead Programmer \\
\hline 8. & Memulai pengembangan sistem proyek & Programmer \\
\hline 9. & Memantau kualitas (Quality Control) dan uji coba & Testers \\
\hline 10. & Pengunggahan proyek Hayyan ke server publik & Programmers \\
\hline 11. & Penjaminan (warranty) dalam bentuk konsultasi akhir pada client & Programmers dan Testers \\
\hline
\end{tabular}


Tabel 2. Predecessor Aktivitas Proyek

\begin{tabular}{|c|c|c|c|}
\hline Aktivitas & Deskripsi Aktivitas & Jumah Hari & Predecessor \\
\hline A & $\begin{array}{l}\text { Mengumpulkan seluruh kebutuhan data dan informasi dari client } \\
\text { Proyek Hayyan }\end{array}$ & 2 Hari & - \\
\hline $\mathrm{B}$ & $\begin{array}{l}\text { Membuat user stories atau deskripsi fungsi proyek berdasarkan } \\
\text { kebutuhan dari proyek Hayyan }\end{array}$ & 3 Hari & A \\
\hline $\mathrm{C}$ & Mengalokasikan manpowers & 1 Hari & $\mathrm{B}$ \\
\hline $\mathrm{D}$ & Mengumpulkan ide desain & 1 Hari & A \\
\hline $\mathrm{E}$ & $\begin{array}{l}\text { Menyusun daftar kebutuhan teknologi (software atau hardware) } \\
\text { yang diperlukan }\end{array}$ & 1 Hari & $\mathrm{D}$ \\
\hline $\mathrm{F}$ & $\begin{array}{l}\text { Menyusun desain dalam bentuk prototype sebagai langkah awal } \\
\text { persetujuan perancangan proyek dengan client }\end{array}$ & 5 Hari & $\mathrm{E}, \mathrm{C}$ \\
\hline G & $\begin{array}{l}\text { Menyusun desain sistem proyek Hayyan yang telah disetujui } \\
\text { oleh client }\end{array}$ & 3 Hari & $\mathrm{F}$ \\
\hline $\mathrm{H}$ & Memulai pengembangan sistem proyek & 15 Hari & G \\
\hline $\mathrm{I}$ & Memantau kualitas (Quality Control) dan uji coba & 4 Hari & $\mathrm{H}$ \\
\hline $\mathrm{J}$ & Pengunggahan proyek Hayyan ke server publik & 2 Hari & $\mathrm{I}$ \\
\hline $\mathrm{K}$ & $\begin{array}{l}\text { Penjaminan (warranty) dalam bentuk konsultasi akhir pada } \\
\text { client dan revisi }\end{array}$ & 1 Hari & $\mathrm{J}$ \\
\hline
\end{tabular}

Dari presedence diagram tersebut dapat memiliki jalur kritis (critical path) pada alur aktivitas A-B-C-F-G-H-I-J-K, yaitu selama 36 hari. Sedangkan untuk jalur lintasan aktivitas lainnya yaitu A-D-E-F-G-H-I-J-Kdilakukan selama 34 hari.

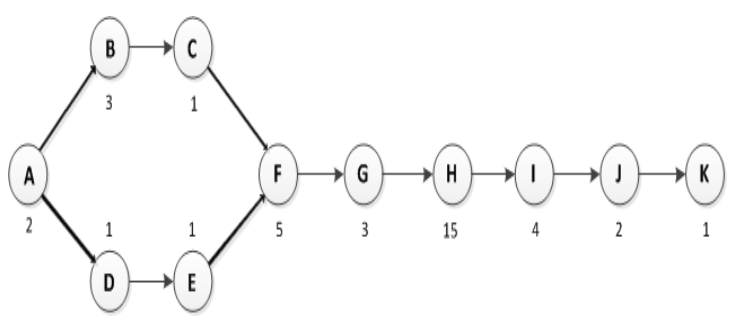

Gambar 3. Presedence Diagram

\section{Rencana Waktu Pelaksanaan Proyek}

Pada Critical Path Method (CPM) dapat dilakukan penentuan waktu-waktu tercepat dan waktu-waktu terlambat dalam menjalankan aktivitas. Pada Tabel 3 dapat menunjukkan jumlah Earlier Start (ES), Earlier Finish (EF), Latest Start (LS), Latest Finish (LF), dan slack time. Contoh perhitungan waktu slack yaitu sebagai berikut:

$$
\text { Slack time } \mathrm{A}=\mathrm{LS}_{\mathrm{A}}-\mathrm{ES}_{\mathrm{A}}
$$$$
=1-0=1
$$

Tabel 3. Slack Time

\begin{tabular}{cccccc}
\hline Aktivitas & ES & EF & LS & LF & Slack Time \\
\hline A & 0 & 2 & 1 & 3 & 1 \\
\hline B & 2 & 5 & 3 & 6 & 1 \\
\hline C & 5 & 6 & 6 & 7 & 1 \\
\hline D & 2 & 3 & 5 & 6 & 3 \\
\hline
\end{tabular}

\begin{tabular}{cccccc}
\hline Aktivitas & ES & EF & LS & LF & Slack Time \\
\hline E & 3 & 4 & 6 & 7 & 3 \\
\hline F & 6 & 11 & 7 & 12 & 1 \\
\hline G & 11 & 14 & 12 & 15 & 1 \\
\hline H & 14 & 29 & 15 & 30 & 1 \\
\hline I & 29 & 33 & 30 & 34 & 1 \\
\hline J & 33 & 36 & 34 & 36 & 1 \\
\hline K & 36 & 37 & 36 & 37 & 0
\end{tabular}

Selanjutnya, untuk menghitung rencana waktu pelaksanaan proyek yaitu dari segi teknik evaluasi dan review proyek atau PERT (Program Evaluation and Review Technique), waktu aktivitas dapat terbagi atas pesimistic $\left(\mathrm{t}_{\mathrm{p}}\right)$, mostlikely $\left(\mathrm{t}_{\mathrm{m}}\right)$ dan Optimistic $\left(\mathrm{t}_{\mathrm{o}}\right)$. Pada Tabel 4 dapat dilihat jumlah waktu sesuai dengan metode PERT.

Tabel 4. PERT

\begin{tabular}{cccc}
\hline Aktivitas & Pesimistic & Most Likely & Optimistic \\
\hline A & 3 & 2 & 2 \\
\hline B & 4 & 3 & 2 \\
\hline C & 1 & 1 & 1 \\
\hline D & 1 & 1 & 1 \\
\hline E & 2 & 1 & 1 \\
\hline F & 7 & 5 & 3 \\
\hline G & 4 & 3 & 3 \\
\hline H & 18 & 15 & 13 \\
\hline I & 4 & 4 & 3 \\
\hline J & 3 & 2 & 2 \\
\hline K & 1 & 1 & 1 \\
\hline
\end{tabular}


Tabel 5. Probabilitas Waktu Aktivitas

\begin{tabular}{cccc}
\hline Aktivitas & Slack Time & te & $\boldsymbol{\sigma}^{\mathbf{2}}$ \\
\hline A & 1 & 2,2 & 0,028 \\
\hline B & 1 & 3,0 & 0,111 \\
\hline C & 1 & 1,0 & 0,000 \\
\hline D & 3 & 1,0 & 0,000 \\
\hline E & 3 & 1,2 & 0,028 \\
\hline F & 1 & 5,0 & 0,444 \\
\hline G & 1 & 3,2 & 0,028 \\
\hline H & 1 & 15,2 & 0,694 \\
\hline I & 1 & 3,8 & 0,028 \\
\hline J & 1 & 2,2 & 0,028 \\
\hline K & 0 & 1,0 & 0,000 \\
\hline
\end{tabular}

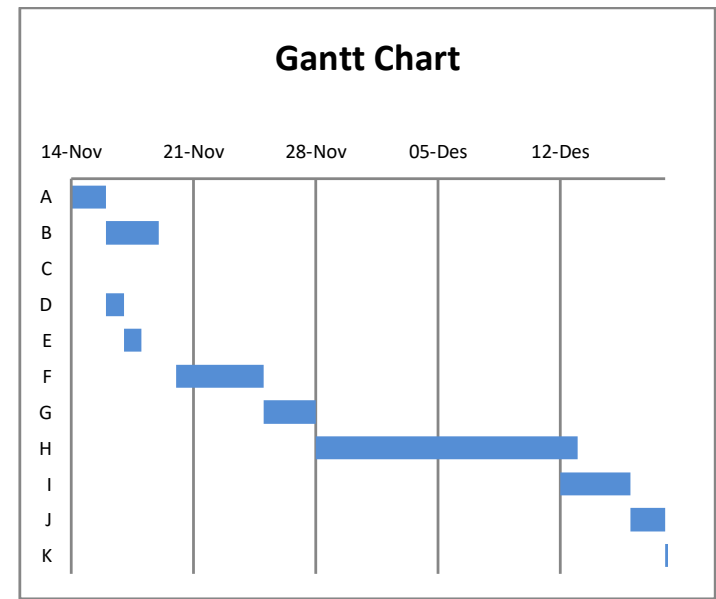

Gambar 4. Gantt Chart

- Perhitungan Expected Time dan Variance

Probabilitas waktu proyek Hayyan dapat dijalankan, dengan memperhitungkan expected time dan variance.

- Expected Time,

contoh perhitungan:

$t e_{\mathrm{A}}=\frac{\mathrm{tp}+4 \mathrm{tm}+\mathrm{to}}{6}=\frac{3+(4 \times 2)+2}{6}=\mathbf{2 , 2}$

- Variance,

contoh perhitungan:

$\sigma_{\mathrm{A}}^{2}=\left(\frac{t p-t o}{6}\right)^{2}=\left(\frac{3-2}{6}\right)=\mathbf{0 , 0 2 8}$

- $\quad$ Perhitungan Probabilitas Jalannya Proyek

$\sigma=\sqrt{\begin{array}{c}\mathrm{VA}+\mathrm{VB}+\mathrm{VC}+\mathrm{VF}+\mathrm{VG} \\ +\mathrm{VH}+\mathrm{VI}+\mathrm{VJ}+\mathrm{VK}\end{array}}$

$\sigma=1,2$

Maka, jika manajer proyek mentargetkan proyek selesai dalam 38 hari atau $\mathrm{X}=38$ hari, maka dapat dihitung probabilitas proyek terselesaikan dalam waktu 38 hari adalah sebagai berikut:
Dengan $\mathrm{x}=38$ hari, maka $\mathrm{Z}=\frac{x-\mu}{\sigma}$

$\mathrm{Z}=\frac{38-38}{1,2}=0 ; \mathrm{P}(\mathrm{Z} \leq 0)=0,5$

$($ Tabel Normal $)=50 \%$

Jika $\mathrm{x}=40$ hari, maka

$$
\begin{array}{r}
\mathrm{Z}=\frac{x-\mu}{\sigma} \\
\mathrm{Z}=\frac{40-38}{1,2}=1,67 ; \mathrm{P}(\mathrm{Z} \leq 1,67) \\
=0,9525=\mathbf{9 5 , 2 5 \%}
\end{array}
$$

Dari hasil perhitungan di atas maka diketahui lebih besar probabilitas proyek terselesaikan dalam waktu 40 hari, yaitu sebesar 95,25\% .

\section{Gantt Chart}

Estimasi waktu pada setiap aktivitas dapat digambarkan dalam suatu Gantt Chart seperti pada Gambar 4 


\section{Pengestimasian Total Biaya Proyek}

1. Teknologi

Aspek teknologi sangat penting dalam menjalankan proyek ini. Total biaya untuk teknologi software yaitu Rp. 15.866.496,- dan total biaya hardware yaitu Rp. 16.309.500,-.

2. Sumber Daya Manusia (SDM)

Dalam menjalankan proyek Hayyan ini, Qiscus Pte Ltd menerapkan kebijakan man days rate atau penerapan tarif biaya pekerja dalam hitungan kerja harian. Sehingga dapat dihitung secara rinci biaya yang diperlukan sesuai dengan hari kerja dan jumlah SDM yang dibutuhkan pada setiap aktivitas, maka didapatkan bahwa total biaya untuk SDM adalah Rp. 14.900.000.

Setelah mengetahui total biaya teknologi dan total biaya SDM, maka dapat dihitung total biaya proyek yang diperlukan bedasarkan pada biayabiaya langsung dan biaya-biaya tidak langsung, yaitu sebesar Rp. 482.841.952,--

\section{Pengestimasian Biaya Proyek yang Dipercepat (Crashing)}

Dalam pelaksanaan proyek Hayyan dapat dilakukan pengestimasian waktu proyek yang lebih cepat dari waktu normalnya. Dalam hal ini disebut sebagai crash time.

Pada Tabel 4.6 menunjukkan jumlah hari dan biaya untuk aktivitas dengan crash time.

Biaya crash cenderung lebih tinggi dibanding biaya nornal karena jumlah hari pelaksanaan aktivitas yang lebih cepat memerlukan penambahan pekerja yaitu seorang desainer dan seorang programmer.

Tabel 6. Durasi Normal dan Crash

\begin{tabular}{clcc}
\hline No. & Item Biaya & $\begin{array}{c}\text { Durasi } \\
\text { Normal }\end{array}$ & $\begin{array}{c}\text { Durasi } \\
\text { Crash }\end{array}$ \\
\hline 1 & $\begin{array}{l}\text { Biaya } \\
\text { Teknologi }\end{array}$ & - & - \\
\hline 2 & Aktifitas A & 2 & 2 \\
\hline 3 & Aktifitas B & 3 & 2 \\
\hline 4 & Aktifitas C & 1 & 1 \\
\hline 5 & Aktifitas D & 1 & 1 \\
\hline 6 & Aktifitas E & 1 & 1 \\
\hline 7 & Aktifitas F & 5 & 3 \\
\hline 8 & Aktifitas G & 3 & 3 \\
\hline 9 & Aktifitas H & 15 & 13 \\
\hline 10 & Aktifitas I & 4 & 3 \\
\hline 11 & Aktifitas J & 2 & 2 \\
\hline 12 & Aktifitas K & 1 & 1 \\
\hline
\end{tabular}

Sehingga, total biaya kumulatif untuk aktivitas normal yaitu sebesar Rp 47.525.996,- sedangkan total biaya kumulatif untuk aktivitas crash adalah sebesar Rp 50.325.996,-.
Perbandingan antara pertambahan biaya dan percepatan waktu penyelesaian proyek dalam 38 hari dapat dihitung yaitu:

Cost Slope $=$

$\frac{\text { Crash Cost-Normal Cost }}{\text { Normal Duration-Crash Duration }}$
Rp 50.325.996-Rp 47.525.996
$=\frac{38-32}{}$

\section{$=\operatorname{Rp} 466.667,-$}

\section{Analisis Jumlah Pelaksanaan Proyek}

Berdasarkan perhitungan dari metode PERT, maka diketahui probabilitas proyek dilaksanakan selama 38 hari adalah $50 \%$. Nilai tersebut menunjukkan bahwa adanya 50\% kemungkinan terjadinya keterlambatan, karena jika perencanaan proyek sesuai dengan jumlah hari pada lintasan kritis, itu berarti perusahaan tidak memberikan waktu toleransi keterlambatan dalam menjalankan proyek di tengah banyaknya ketidakpastian kondisi. Ketidakpastian dari perusahaan Qiscus Pte Ltd dapat bersumber dari sistem operasi, sumber daya manusia, biaya, lingkungan, dan lain sebagainya. Sedangkan ketidakpastian dari perusahaan Hayyan dapat terjadi seperti penambahan permintaan fitur website atau lain sebagainya.

Berdasarkan perhitungan, maka diketahui sebesar 95,25\% proyek Hayyan dapat diselesaikan oleh Qiscus Pte Ltd yang menunjukkan bahwa adanya 2 hari lebih lambat dibandingkan jumlah hari pada lintasan kritis sebagai toleransi realistis untuk keterlambatan proyek yang dilakukan Qiscus Pte Ltd.

\section{Analisis Project Crashing}

Dalam melaksanakan proyek Hayyan dapat dilakukan percepatan aktivitas proyek (Crashing) tetapi dengan adanya trade off antara waktu dan biaya. Percepatan yang dapat dilakukan dengan mengurangi jumlah aktivitas sebanyak 6 hari, yaitu pada aktivitas proyek normal dilakukan selama 38 hari menjadi 32 hari.Percepatan tersebut dapat dilakukan dengan cara menambah jumlah pekerja, yaitu seorang desainer dan seorang programmer. Sehingga, total biaya crashing meningkat akibat adanya penambahan biaya langsung. Trade off ini yang dapat disampaikan Qiscus Pte Ltd pada client dimana client yang dapat menentukan untuk memilih pengerjaan proyek yang lebih cepat dengan biaya yang lebih tinggi atau proyek yang lebih lama dengan biaya yang lebih rendah.

\section{Kesimpulan}

Dalam menjalankan proyek Hayyan oleh Qiscus Pte Ltd, terdapat 4 aspek kerja yaitu terkait dengan tahap pengumpulan data $\&$ informasi dan perekrutan 
SDM (requirement), tahap perancangan desain proyek (design), tahap pengembangan sistem (development), dan tahap penjaminan kualitas (integration \& test) yang membutuhkan 5 orang pekerja dan dalam waktu selama 38 hari bedasarkan Critical Path.

Probabilitas aktivitas dilaksanaakan sesuai dengan jumlah hari pada critical path adalah $50 \%$. Terdapat probabilitas penundaan aktivitas sebesar $50 \%$, yang artinya proyek mungkin dilaksanakan lebih dari 38 hari.

Percepatan pelaksanaan proyek Hayyan (Crashing) menghasilkan suatu trade off bagi client terhadap biaya dan waktu yang dibutuhkan. Dengan adanya crashing menimbulkan peningkatan biaya menjadi Rp 50.325.996,- sedangkan total biaya proyek tanpa adanya crashing sebesar Rp 47.525.996,-.

\section{Daftar Pustaka}

Dimyati, D. H., \& Nurjaman, K. (2014). Manajemen Proyek. Yogyakarta: Pustaka Setia.

Duncan, W. R. (1996). A Guide to The Project Management Body of Knowledge. Sylva: PMI Communication.

Soeharto, I. (2002). Studi Kelayaan Proyek Industri . Jakarta : Erlangga.

Soeharto, I. 1999. Manajemen Proyek (Dari Konseptual Sampai Operasional ). Jakarta : Erlangga.

Rev, E. (2003). Work Breakdown Structure. America: U.S. Department of Energy. 